\title{
HIV Transmission Potential Among Local and Migrant Factory Workers in Kolkata, India
}

\author{
Alok Kumar Deb · Manjari Deb • \\ Malay Kumar Saha $\cdot$ Shantanu Chakraborty $\cdot$ \\ Sujit Kumar Bhattacharya $\cdot$ Roger Detels
}

Published online: 24 March 2009

(C) The Author(s) 2009. This article is published with open access at Springerlink.com

\begin{abstract}
Migrant workers in India play a key role in the spread of HIV. Kolkata is a common destination for workers, who may acquire infection and transmit it to their wives and/or other sexual partners. We investigated sexual relations and condom use by factory workers. Migrant and local factory workers were randomly selected from five wards of Kolkata. Information was collected about demographic and socio-economic characteristics, sexual relationships, condom usage, and perceptions and intent to use condoms. Condom use was very low in both groups of workers, particularly among migrants. Many married workers visited female sex workers but never used condoms. Few intended to use condoms, and if they did, it did not always translate into actual usage. There is great potential for transmission of HIV/sexually transmitted infections by these workers. Carefully designed intervention and education programs in the context of low literacy and cultural norms are urgently needed.
\end{abstract}

Keywords Condoms - India - HIV .

Sexually transmitted infections (STIs) $\cdot$ Migrants

A. K. Deb - M. K. Saha - S. Chakraborty

National Institute of Cholera and Enteric Diseases,

Kolkata, India

M. Deb

Barrackpore Population Health Study, Barrackpore,

Kolkata, India

S. K. Bhattacharya

Indian Council of Medical Research, New Delhi, India

R. Detels $(\bowtie)$

School of Public Health, University of California,

Los Angeles, CA 90095-1772, USA

e-mail: detels@ucla.edu

\section{Introduction}

India, with a population of more than one billion, has not been spared from the HIV epidemic. According to the 2005 UNAIDS estimate (UNAIDS 2005), India had 5.7 million people living with HIV. However, with support from UNAIDS and the World Health Organization (WHO) in 2006, a revised estimate from the National AIDS Control Organization (NACO 2007b www.nacoonline.org/Quick_ Links/HIV_Data) estimated that the HIV prevalence in the country could actually be lower, at $\sim 2.5$ million infected people.

Sexual transmission accounts for more than $85 \%$ of all HIV infections in India (NACO 2007a National AIDS Control Program III www.nacoonline.org/National_AIDS_ Control_Program/Prevention_Strategies). One critical consideration for most sexually transmitted HIV epidemics is the use of condoms during sex. In Thailand and Cambodia, significant success has been achieved in lowering the spread and prevalence of HIV, as well as other bacterial sexually transmitted infections (STIs), through promotion of $100 \%$ condom use for commercial sex (WHO 2000). Researchers have found that regular and consistent use of condoms may reduce the transmission of HIV infections by 87-95\% (CDC 2002 www.cdc.gov/ nchstp/od/condoms.pdf; Foss et al. 2004). NACO in India has also emphasized condom use to reduce the risk of HIV transmission at the population level. Condom use among sexually active individuals in India, however, remains very low in almost all groups of sexually active people, including married men, unmarried men (Dunn et al. 2004), university students (Sachdev 1998), urban slum dwellers (Bhatia et al. 2005), rural men (Dunn et al. 2004), truck drivers (Singh and Malaviya 1994; Ubaidullah 2004), etc., and has been documented even in high-risk groups such as 
commercial sex workers (NACO 2001; Dandona et al. 2005a), non-regular sex partners (Kumar et al. 1997), and men having sex with men (Go et al. 2004; Dandona et al. 2005b; Setia et al. 2006). Thus, despite the currently estimated low HIV prevalence, the opportunity for developing a widespread epidemic persists.

Initially, most cases of HIV infection in India remained confined within specific high-risk groups (e.g., commercial sex workers, their clients, and STI patients) in major urban areas and among injecting drug users in the north-eastern states (Sarkar et al. 1993). Later, evidence from different parts of India suggested that in addition to an increasing prevalence among the high-risk groups, HIV had also started to spread from high-risk groups to the general population, and from urban to rural areas (Arole et al. 2005; NACO Annual Report 20022003, 2003-2004; Pallikadavath et al. 2005). This urbanto-rural spread has serious implications, considering the vast Indian population (more than 742 million) living in rural areas (Census of India 2001), the often inadequate and/or inaccessible health facilities in rural communities, and its potential social and economic impact on the country (Anand et al. 1999; Pallikadavath et al. 2005). Studies in India have also suggested that two specific rural populations are particularly vulnerable-those along truck routes (Singh and Malaviya 1994) and those who are the sources of labor migrating to urban areas (Lamptey 2002; Solomon et al. 1998). Several studies conducted in other countries have found that migrants are especially vulnerable because of less education, less awareness about HIV/STIs, less access to and utilization of local health care services, and higher risk behaviors related to HIV and STIs. Moreover, their role in transmitting these infections to their homes in rural areas has been suggested (Coffee et al. 2007; Kramer et al. 2008; Lagarde et al. 2003; Li et al. 2006; Smith-Estelle and Gruskin 2003; Sowell et al. 2008). Unfortunately, apart from a few studies (Gupta and Mitra 1999; Panda et al. 2000), little information in this regard is available in India.

More than 90 million males (i.e., more than $25 \%$ of adult males) in India are migrants. About 51 million males migrate from rural areas, and nearly a quarter of them migrate from one state to another (Census of India 2001). This is likely to increase further (National Sample Survey 1992-1993; National Sample Survey Report No. 470, 2001; UNESCO 2002), due to growing economic disparities (Haberfeld et al. 1999; PRAXIS 2002; Srivastava 1998). Thus, these vast numbers of migrants may constitute an important risk group for HIV/STIs, especially in acquiring the infection and transmitting it back to the rural population. Hence, considering the dearth of information on this important topic, the present study was undertaken to gain insights into the possible role of migrants in spreading HIV and STIs by comparing the patterns of sexual risk behaviors and condom use by local and migrant workers, and to identify predictors of condom use and the potential for transmission of HIV and other STIs from migrant workers to the general population. Specifically, we hypothesized that compared to local workers, migrant workers have higher HIV risk behaviors, along with lower use of condoms during sex with high-risk partners, as well as with their usual partners, increasing the possibility of transmitting infection from their high-risk partners to their usual (low-risk) partners.

\section{Methods}

\section{Study Site and Participants}

Kolkata, a metropolitan city in the eastern Indian state of West Bengal, is one of the most common destinations for migrant workers from poorer neighboring states such as Bihar (currently, Bihar and Jharkhand), Orissa, and Uttar Pradesh. According to the latest available information, $\sim 20 \%$ of the total population of 13.4 million in Kolkata are migrants (Census of India 1991). About half (53\%) of them are male, of whom $33.7 \%$ are illiterate and $71.5 \%$ are engaged in low-grade work. About $34 \%$ of all migrants in Kolkata originate from another state in India.

The present study was conducted among 18-45-year-old male factory workers in five municipal corporation wards (\#14, 28, 29, 30 and 35) in Kolkata. In total, we enumerated 811 small- and medium-sized factories in these five wards. Their most common products were shoes and other leather products, textiles, and stationery.

In these 811 factories, there was a total of 7,009 workers-6,753 males (96.3\%) and 256 females (3.7\%), of whom 6,192 males (91.7\%) were aged between 18 and 45 years; $3,050(49.3 \%)$ of them were local workers, 1,285 (20.7\%) came from another district within the state (interdistrict migrants), and 1,857 (30\%) came from another state (inter-state migrants). For this study, 2,850 (93.4\%) local workers and 1,764 (95\%) inter-state migrant workers (henceforth referred to as "migrant workers") were eligible to participate. We randomly selected 402 workers in each group (locals and migrants) using a probability-proportionate-to-size (PPS) sampling scheme, where the number of workers selected from each ward was proportionate to the distribution (relative size) of each group of eligible workers in the five selected wards. In total, $11(1.4 \%)$ of the workers approached refused to participate at initial contact; in those cases, we asked the next eligible worker to participate. 


\section{Definitions of Variables and Data Collection}

"Migrant workers" were defined as inter-state migrants who had been working in Kolkata for a year or more and visited their home at least once a year. "Local workers" were residents of Kolkata working in the surveyed venues for at least 1 year. All of the 804 selected participants completed an anonymous face-to-face questionnaire-based interview after completing written informed consent. Information was collected on socio-demographic characteristics, including basic migration-related characteristics of the migrants. Condom use patterns were assessed as "always", "sometimes", and "never" with specific types of sex partners. Perceptions about condoms and intention to use them were assessed through a set of statements (Table 1) constructed on five-point Likert scales ranging from "strongly agree" to "strongly disagree". As measured by Cronbach's alpha, the internal consistencies of all ten items, and the six perception and the four intention statements, were $0.84,0.75$, and 0.76 , respectively. From the given responses, we computed summary scores with reverse coding of the items wherever appropriate. For condom perceptions, scores ranged from 6 to $30(6=$ strongly negative perception, $18=$ neither negative nor positive,

Table 1 Statements to assess perceptions about condoms and intent to use them

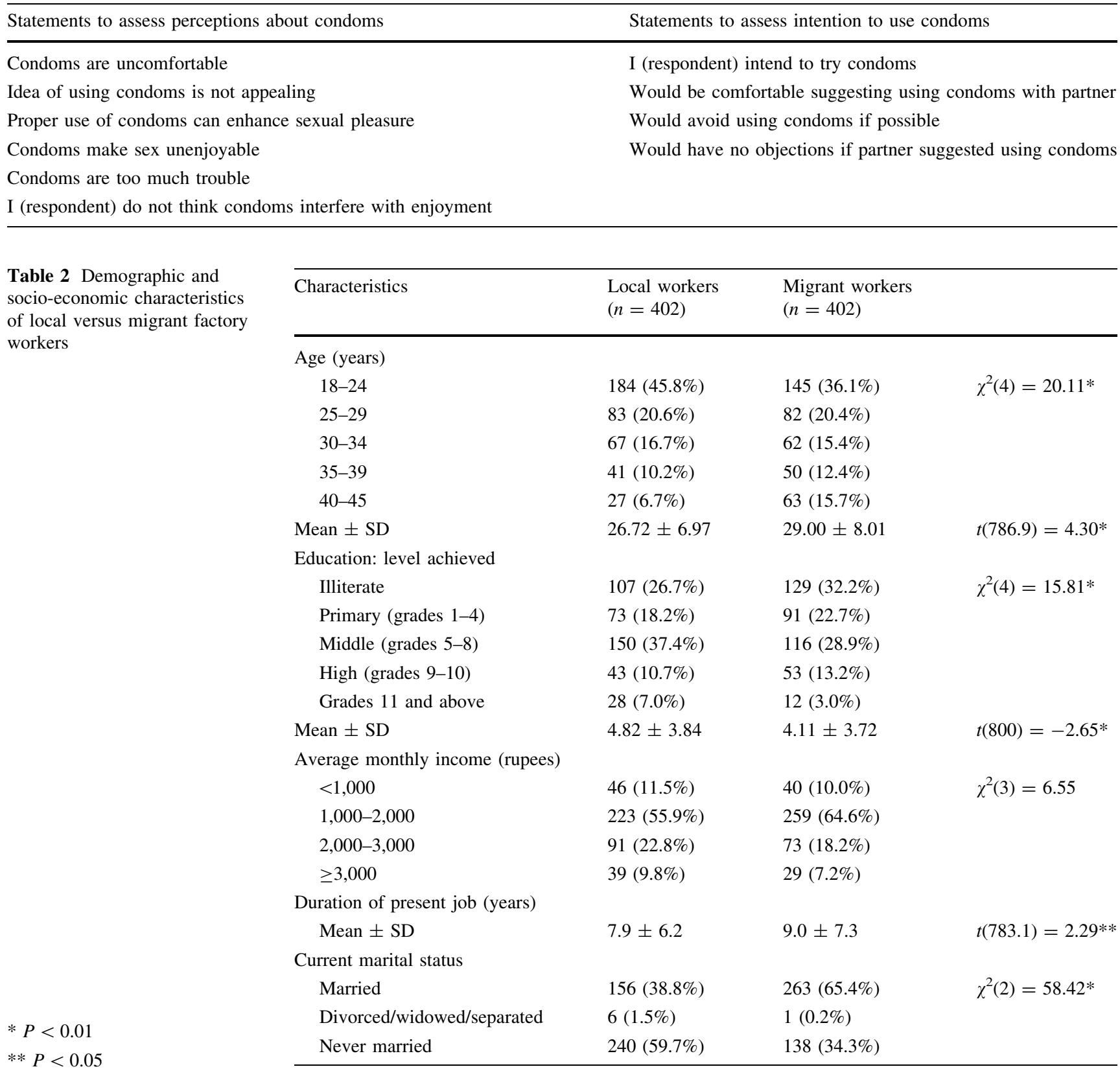


and $30=$ strongly positive perception). For intent to use condoms, the range was 4-20 ( 4 = strong lack of intention to use, 12 = neither intent nor lack thereof, and $20=$ strong intent). Assessment of knowledge about HIV/ AIDS and STIs was limited to asking whether they had ever heard of these infections, and sexual risk behaviors were assessed by asking whether they ever had sex with: (1) a female sex worker (FSW); (2) a girlfriend; (3) any female partner other than wife, FSW, or girlfriend; and/or (4) any male partner.

\section{Data Analysis}

All data were entered into an EXCEL spreadsheet and analyzed using STATA/SE 8.0 or SPSS 13.0 statistical software. Differences in characteristics between the two groups of workers were assessed through chi-square tests (for proportions) or Student's $t$-test (for means). Where appropriate, we tested differences in means among multiple groups using one-way ANOVA. Multivariate logistic regression analyses were used to identify independent predictors of not using condoms, adjusting for effects of other relevant variables, regardless of their magnitude of association in the descriptive analyses.

The study was approved by the institutional review boards of the National Institute for Cholera and Enteric Diseases (India) and the University of California, Los Angeles.

\section{Results}

Of the 402 migrant workers surveyed, the majority (302; $75.1 \%$ ) came from the state of Bihar, which is adjacent to West Bengal. Most of these workers $(350 ; 87.1 \%)$ originated from a rural area; only a few were from a suburban area $(27 ; 6.7 \%)$ or a town or city $(25 ; 6.2 \%)$. On average, they had stayed in Kolkata for 12.7 years (range $1-35$ years). The majority of these workers $(271 ; 67.4 \%)$ visited their homes more than once a year (up to 11 times per year); 68 (16.9\%) visited at least once a month, and 63 $(15.7 \%)$ visited only once a year. The demographic and socio-economic characteristics of the two groups of workers are presented in Table 2. Overall, local workers were younger and had higher levels of education than the migrant workers. Although they had a higher monthly income, the difference was not significant. However, compared to the locals, migrants had worked longer at their jobs [mean duration. 7.9 vs. 9.0 years; $t(783.1)=2.29$, $P<0.05]$. Migrant workers were more likely than local workers to be married $\left[65.4 \%\right.$ vs. $38.8 \% ; \chi^{2}(2)=58.4$, $P<0.01]$. While most $(94.9 \%)$ of the local married workers were living with their wives, less than a third
$(28.5 \%)$ of the married migrant workers were. We found that 65.7 and $79.4 \%$ of local and migrant factory workers, respectively, had ever had $\operatorname{sex}\left[\chi^{2}(1)=18.88, P<0.01\right]$ (data not shown). Among those who ever had sex, the type of sexual partners reported by the locals and migrants, respectively, included wives $\left[61.4 \%\right.$ vs. $82.0 \% ; \chi^{2}(1)=$ $31.09, P<0.01]$, regular girlfriends $[10.9 \%$ vs. $6.8 \%$; $\left.\chi^{2}(1)=3.15, P>0.05\right]$, FSWs [57.2\% vs. $37.9 \% ; \chi^{2}(1)=$ 21.73, $P<0.01$ ], other female sex partners (other than wife, girlfriend or FSW) $\left[14.4 \%\right.$ vs. $12.1 \% ; \chi^{2}(1)=0.69$, $P>0.05]$, and other male partners $[13.5 \%$ vs. $7.4 \%$; $\left.\chi^{2}(1)=5.78, P<0.05\right]$.

As shown in Table 3, a large proportion of the participants had never used a condom during sex, particularly the migrant workers. When condom use was dichotomized into "ever" and "never", compared to local workers, significantly more migrant workers never used condoms with their wives $\left[\chi^{2}(1)=21.78, \quad P<0.01\right]$, sex workers $\left[\chi^{2}(1)=18.88, P<0.05\right]$, or other partners $\left[\chi^{2}(1)=7.46\right.$, $P<0.01]$. Six percent of migrant workers and $8.7 \%$ of local workers admitted to having sex with other men, and none had used condoms with them. No differences were noted for having sex with girlfriends. As a large proportion in each group never used condoms, we also explored the relationship between the workers' demographic characteristics and non-use of condoms with wives or FSWs

Table 3 Use of condoms with various sex partners by local and migrant factory workers

\begin{tabular}{lcc}
\hline Type of sex partner & Local workers & Migrant workers \\
\hline Wife & $2(1.2 \%)$ & $1(0.4 \%)$ \\
$\quad$ Always & $80(49.7 \%)$ & $74(28.0 \%)$ \\
$\quad$ Sometimes & $79(49.1 \%)$ & $189(71.6 \%)$ \\
$\quad$ Never & $2(6.9 \%)$ & $1(4.5 \%)$ \\
Girlfriend & $2(6.9 \%)$ & $3(13.6 \%)$ \\
$\quad$ Always & $25(86.2 \%)$ & $18(81.8 \%)$ \\
$\quad$ Sometimes & & $4(10.3 \%)$ \\
Never & $5(13.2 \%)$ & $2(5.1 \%)$ \\
Other female sex partners & $11(28.9 \%)$ & $33(84.6 \%)$ \\
Always & $22(57.9 \%)$ & \\
Sometimes & & $26(21.7 \%)$ \\
Never & $43(29.9 \%)$ & $36(30.0 \%)$ \\
Female sex workers & $52(36.1 \%)$ & $58(48.3 \%)$ \\
Always & $49(34.0 \%)$ & $24(100.0 \%)$ \\
Sometimes & & \\
Never & $35(100.0 \%)$ &
\end{tabular}

Number of workers in each group represents workers having respective type of sex partners 
Table 4 Relationship between workers' demographic characteristics and non-use of condoms with wife or female sex workers (FSWs)

\begin{tabular}{|c|c|c|c|c|}
\hline \multirow[t]{2}{*}{ Characteristics } & \multicolumn{2}{|l|}{ Local workers } & \multicolumn{2}{|l|}{ Migrant workers } \\
\hline & $\begin{array}{l}\% \text { Never used } \\
\text { condoms with } \\
\text { wife (if married) }\end{array}$ & $\begin{array}{l}\% \text { Never used } \\
\text { condoms with } \\
\text { FSW (if visited) }\end{array}$ & $\begin{array}{l}\% \text { Never used } \\
\text { condoms with } \\
\text { wife (if married) }\end{array}$ & $\begin{array}{l}\% \text { Never used } \\
\text { condoms with } \\
\text { FSW (if visited) }\end{array}$ \\
\hline \multicolumn{5}{|l|}{ Age groups (years) } \\
\hline $18-24$ & 63.2 & 31.6 & 69.4 & 30.8 \\
\hline $25-29$ & 53.7 & 21.6 & 80.0 & 39.1 \\
\hline $30-34$ & 40.9 & 44.4 & 63.8 & 56.5 \\
\hline $35-39$ & 50.0 & 38.5 & 74.5 & 70.6 \\
\hline \multirow[t]{2}{*}{$40-45$} & 42.9 & 60.0 & 69.8 & 66.7 \\
\hline & $\chi^{2}(4)=3.36$ & $\chi^{2}(4)=7.11$ & $\chi^{2}(4)=4.19$ & $\chi^{2}(4)=12.01^{*}$ \\
\hline \multicolumn{5}{|l|}{ Education level (grades) } \\
\hline Illiterate $(0)$ & 60.7 & 42.1 & 76.0 & 57.5 \\
\hline Primary (1-4) & 45.5 & 40.7 & 73.8 & 50.0 \\
\hline Middle (5-8) & 38.2 & 28.8 & 68.9 & 43.8 \\
\hline High (9-12) & 55.6 & 30.8 & 64.5 & 30.0 \\
\hline \multirow[t]{2}{*}{ College $(>12)$} & 42.9 & 14.3 & 33.3 & 25.0 \\
\hline & $\chi^{2}(4)=6.07$ & $\chi^{2}(4)=3.64$ & $\chi^{2}(4)=6.41$ & $\chi^{2}(4)=3.87$ \\
\hline \multicolumn{5}{|l|}{ Marital status } \\
\hline Ever married & 49.1 & 38.2 & 71.6 & 55.2 \\
\hline \multirow[t]{2}{*}{ Never married } & - & 30.3 & - & 30.3 \\
\hline & & $\chi^{2}(1)=1.02$ & & $\chi^{2}(1)=5.92 *$ \\
\hline \multicolumn{5}{|l|}{ Ever heard of HIV/AIDS } \\
\hline Yes & 47.3 & 33.3 & 69.3 & 47.2 \\
\hline \multirow[t]{2}{*}{ No } & 70.0 & 50.0 & 83.8 & 57.1 \\
\hline & $\chi^{2}(1)=1.93$ & $\chi^{2}(1)=0.48$ & $\chi^{2}(1)=3.25$ & $\chi^{2}(1)=0.49$ \\
\hline \multicolumn{5}{|c|}{ Place of origin (for migrants) } \\
\hline Rural area & - & - & 72.9 & 50.5 \\
\hline \multirow[t]{2}{*}{ Urban/semi-urban area } & & & 60.7 & 27.3 \\
\hline & & & $\chi^{2}(1)=1.82$ & $\chi^{2}(1)=2.15$ \\
\hline \multicolumn{5}{|l|}{ Duration of stay in Kolkata } \\
\hline $1-5$ years & - & - & 72.4 & 37.5 \\
\hline $5-10$ years & & & 75.5 & 54.5 \\
\hline \multirow[t]{2}{*}{ Over 10 years } & & & 70.4 & 50.0 \\
\hline & & & $\chi^{2}(2)=0.50$ & $\chi^{2}(2)=1.55$ \\
\hline
\end{tabular}

$* P<0.05$

(Table 4). Table 4 demonstrates that condom use with wives was similar across age groups in both groups of workers, and a high proportion (particularly migrants) never used condoms with their wives. Older workers in both groups were less likely to use condoms with sex workers, significantly so among migrants. Although level of education had no statistically significant effect on condom use either with wives or with FSWs by either group, workers with less education were less likely to use condoms. Similarly, there was no statistical difference in condom usage between workers who had ever heard of HIV/AIDS and those who had not. Not hearing about HIV/
AIDS was more common among those not using condoms in both groups. Married participants in both groups (particularly migrants) were more likely to not use condoms with FSWs than unmarried participants. Among migrants, the likelihood of not using condoms with either wives or FSWs was higher if they originated from a rural area; duration of stay in Kolkata did not affect their condom use. These findings probably reflect the fact that compared to unmarried workers, married workers were older, had less education, and were less likely to have heard about HIV/ AIDS than the younger workers, and hence were less likely to use condoms. 
As many as $43.9 \%$ of unmarried local participants and $40.6 \%$ of unmarried migrants had engaged in sex. Extramarital sex was also common. Among the currently married workers, $44.2 \%$ of the locals and $33.1 \%$ of the migrants had visited sex workers $\left[\chi^{2}(1)=5.21\right.$, $P<0.05]$. Only $24.6 \%$ of these locals and $13.8 \%$ of these migrants always used condoms with sex workers; $38.8 \%$ of these locals and $54.6 \%$ of these migrants never used condoms $\left[\chi^{2}(1)=3.79, P>0.05\right]$ with sex workers (data not shown). Thus, condom use with sex workers was even lower among married workers, raising serious concerns about the high potential for transmission of HIV and other STIs from this high-risk group to their wives.

To determine the possible reasons for such low condom use, we assessed participants' perceptions and intentions of condom use. Table 5 shows that on average, both groups of participants' perceptions were neither negative nor positive; migrants had slightly negative perceptions, and locals, slightly positive. On the other hand, both groups showed some intent to use condoms, with locals showing a stronger intent than migrants. In both groups, perception and intention were significantly dependent on age, marital status, and whether they had ever heard of HIV/AIDS and STIs; among migrants, this also depended on education level (Table 6).

To determine whether there was any existing relationship between perceptions of condoms and intent to use them, we calculated overall correlation among them, which showed a significant positive correlation $(0.66, P<0.01)$, as evidenced in the scatterplot in Fig. 1. A correlation between positive perceptions and intent to use condoms was also evident in both groups of workers. Moreover, a significant positive association $(P<0.05)$ was also noted between different levels of intent to use condoms and actual usage (Fig. 2).
Despite the correlation, the participants did not have high levels of either positive perceptions about condoms or intent to use them (Table 5). This probably led to very low condom usage, even with sex workers, especially among the migrants. Married participants were more involved in high-risk sex, and condom use was very low with their wives, indicating a high potential for transmission of HIV or other STIs from these individuals to their wives.

Within our data, we tried to identify the factors that correlated with condom use by the participants with wives or FSWs. Table 7 presents the results of logistic regression analysis that incorporated the workers' socioeconomic characteristics, perceptions of condoms and intent to use them, and sexual experience. Table 7 shows that there is a trend (albeit non-significant) that younger participants among the locals were less likely to use condoms with their wives, while older migrants were less likely to use condoms with FSWs. Migrant workers in the 25- to 29-year age group were also significantly less likely to use condoms with their wives than older (40- to 45-year-old) migrants. Education level and monthly income had no relationship with condom use; however, there was a non-significant trend that participants with less education used condoms less frequently. Condom use also did not depend on whether the workers had ever heard of HIV/AIDS or whether they had other sex partners.

Although condom use with FSWs did not depend on marital status, use with wives did depend upon whether the participants visited FSWs; if they visited FSWs, they were more likely to use condoms with their wives. This effect was statistically significant among the migrants. Workers with stronger intent to use condoms were significantly more likely to use them with their wives (both locals and migrants) or FSWs (locals only); however, migrants with

Table 5 Participants' perceptions about condoms and intent to use them

\begin{tabular}{|c|c|c|c|}
\hline Characteristics & $\begin{array}{l}\text { Local } \\
\text { workers } \\
(n=402)\end{array}$ & $\begin{array}{l}\text { Migrant } \\
\text { workers } \\
(n=402)\end{array}$ & \\
\hline Ever heard about condoms & $395(98.3 \%)$ & $376(93.8 \%)$ & $\chi^{2}(1)=10.59 *$ \\
\hline $\begin{array}{l}\text { If having heard about condoms, number of years } \\
\text { since first hearing about them (mean } \pm \text { SD) }\end{array}$ & $8.1 \pm 5.3$ & $8.9 \pm 6.5$ & $t(721.9)=1.83$ \\
\hline $\begin{array}{l}\text { Summary score of awareness/ } \\
\left.\text { perceptions of condoms (on a scale of } 6 \text { to } 30^{\mathrm{a}}\right)(\text { mean } \pm \mathrm{SD})\end{array}$ & $18.9 \pm 3.8$ & $17.9 \pm 3.7$ & $t(802)=4.02^{*}$ \\
\hline $\begin{array}{l}\text { Summary score of intention to use condoms } \\
\text { (on a scale of } 4 \text { to } 20^{b} \text { ) }\end{array}$ & $14.1 \pm 3.4$ & $12.6 \pm 3.7$ & $t(795.3)=6.11^{*}$ \\
\hline
\end{tabular}


Table 6 Association of workers' characteristics with their perceptions about condoms and intent to use them

\begin{tabular}{|c|c|c|c|c|}
\hline \multirow[t]{2}{*}{ Characteristics } & \multicolumn{2}{|c|}{ Local workers $(n=402)$} & \multicolumn{2}{|c|}{ Migrant workers $(n=402)$} \\
\hline & $\begin{array}{l}\text { Perception score } \\
(\text { mean } \pm \text { SD) }\end{array}$ & $\begin{array}{l}\text { Intention score } \\
(\text { mean } \pm \text { SD) }\end{array}$ & $\begin{array}{l}\text { Perception score } \\
(\text { mean } \pm \text { SD) }\end{array}$ & $\begin{array}{l}\text { Intention score } \\
(\text { mean } \pm \text { SD) }\end{array}$ \\
\hline
\end{tabular}

\begin{tabular}{|c|c|c|c|c|}
\hline \multicolumn{5}{|l|}{ Age groups (years) } \\
\hline $18-24$ & $19.4 \pm 3.8$ & $14.7 \pm 3.2$ & $18.3 \pm 3.5$ & $13.3 \pm 3.6$ \\
\hline $25-29$ & $19.0 \pm 3.8$ & $14.5 \pm 3.2$ & $18.5 \pm 3.3$ & $13.0 \pm 3.3$ \\
\hline $30-34$ & $19.4 \pm 3.6$ & $14.4 \pm 3.0$ & $16.9 \pm 4.4$ & $12.4 \pm 3.7$ \\
\hline $35-39$ & $17.5 \pm 3.9$ & $12.1 \pm 3.6$ & $17.5 \pm 4.1$ & $12.3 \pm 3.6$ \\
\hline \multirow[t]{2}{*}{$40-45$} & $16.7 \pm 3.5$ & $11.3 \pm 3.9$ & $17.2 \pm 3.6$ & $10.6 \pm 3.9$ \\
\hline & $F(4)^{\mathrm{a}}=4.6^{* *}$ & $F(4)=10.6^{* *}$ & $F(4)=2.6^{*}$ & $F(4)=6.4 * *$ \\
\hline \multicolumn{5}{|c|}{ Education level (grades) } \\
\hline Illiterate $(0)$ & $19.4 \pm 3.9$ & $14.3 \pm 3.4$ & $18.6 \pm 3.5$ & $13.3 \pm 3.8$ \\
\hline Primary (1-4) & $17.9 \pm 4.0$ & $13.4 \pm 3.7$ & $17.9 \pm 3.7$ & $12.2 \pm 3.4$ \\
\hline Middle (5-8) & $19.0 \pm 3.9$ & $14.1 \pm 3.3$ & $17.0 \pm 3.9$ & $11.8 \pm 3.9$ \\
\hline High (9-12) & $18.9 \pm 3.6$ & $14.1 \pm 3.2$ & $17.8 \pm 3.4$ & $12.7 \pm 3.4$ \\
\hline \multirow[t]{2}{*}{ College $(>12)$} & $19.7 \pm 2.7$ & $15.5 \pm 3.0$ & $17.1 \pm 4.9$ & $12.8 \pm 3.9$ \\
\hline & $F(4)=1.8$ & $F(4)=1.9$ & $F(4)=3.1^{*}$ & $F(4)=2.8^{*}$ \\
\hline \multicolumn{5}{|l|}{ Marital status } \\
\hline Ever married & $18.1 \pm 4.2$ & $13.1 \pm 3.7$ & $17.6 \pm 4.0$ & $12.1 \pm 3.7$ \\
\hline \multirow[t]{2}{*}{ Never married } & $19.5 \pm 3.5$ & $14.8 \pm 3.1$ & $18.4 \pm 3.1$ & $13.5 \pm 3.5$ \\
\hline & $F(1)=14.4 * *$ & $F(1)=24.3^{* *}$ & $F(1)=4.3^{*}$ & $F(1)=12.5^{* *}$ \\
\hline \multicolumn{5}{|c|}{ Ever heard of HIV/AIDS } \\
\hline Yes & $19.0 \pm 3.9$ & $14.2 \pm 3.4$ & $18.0 \pm 3.8$ & $12.8 \pm 3.8$ \\
\hline \multirow[t]{2}{*}{ No } & $16.9 \pm 3.4$ & $11.2 \pm 2.9$ & $16.7 \pm 3.4$ & $11.1 \pm 3.1$ \\
\hline & $F(1)=4.5^{*}$ & $F(1)=12.3^{* *}$ & $F(1)=5.1^{*}$ & $F(1)=8.6^{* *}$ \\
\hline \multicolumn{5}{|l|}{ Ever heard of STIs } \\
\hline Yes & $19.5 \pm 3.7$ & $14.5 \pm 3.2$ & $18.2 \pm 3.6$ & $12.4 \pm 3.7$ \\
\hline \multirow[t]{2}{*}{ No } & $17.9 \pm 3.9$ & $13.3 \pm 3.8$ & $17.3 \pm 3.8$ & $12.8 \pm 3.6$ \\
\hline & $F(1)=15.6^{* *}$ & $F(1)=10.3^{* *}$ & $F(1)=4.9^{*}$ & $F(1)=1.1$ \\
\hline \multicolumn{5}{|c|}{ Place of origin (for migrants) } \\
\hline Rural area & - & - & $17.9 \pm 3.7$ & $12.4 \pm 3.7$ \\
\hline \multirow{2}{*}{\multicolumn{2}{|c|}{ Urban/semi-urban area }} & & $17.7 \pm 3.9$ & $13.3 \pm 3.7$ \\
\hline & & & $F(1)=0.1$ & $F(1)=2.5$ \\
\hline \multicolumn{5}{|c|}{ Duration of stay in Kolkata (for migrants) } \\
\hline $1-5$ years & - & - & $18.4 \pm 3.4$ & $13.2 \pm 3.4$ \\
\hline $5-10$ years & & & $18.3 \pm 3.5$ & $12.9 \pm 3.6$ \\
\hline \multirow[t]{2}{*}{ Over 10 years } & & & $17.4 \pm 3.9$ & $12.1 \pm 3.9$ \\
\hline & & & $F(2)=2.9$ & $F(2)=2.9$ \\
\hline
\end{tabular}

$* P<0.05$

** $P<0.01$

a ANOVA $F(d f)$ study. Consistent condom use has been shown to reduce the risk of acquiring STIs, including HIV, and also reduces the transmission of these pathogens to sexual partners (CDC 2002 www.cdc.gov/nchstp/od/condoms. pdf). Condom use is now well recognized as one of the major approaches to control HIV and other STIs. Since the recognition of increasing spread of HIV infection among comparatively lower risk groups through heterosexual contact, condom use has gained even more importance. However, the impact of condoms has not 


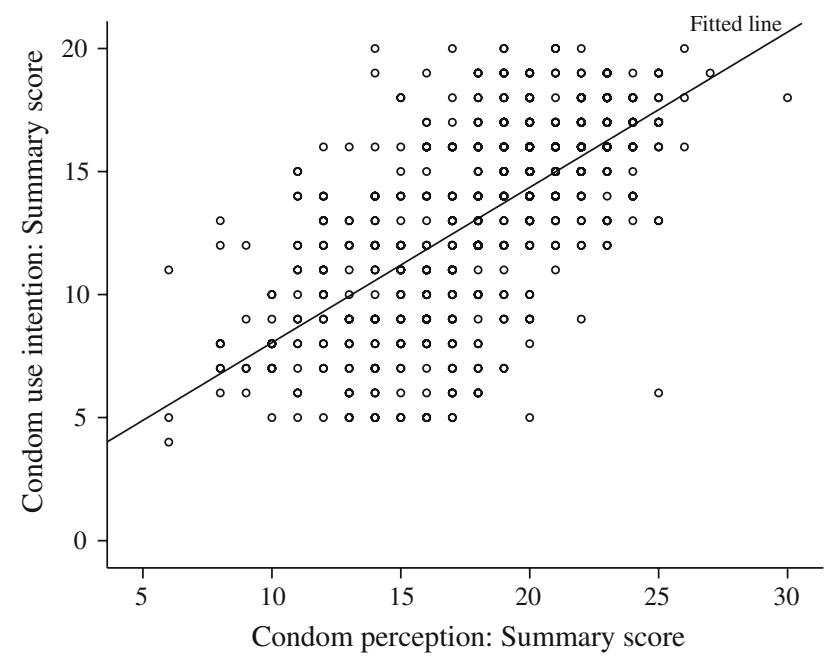

Fig. 1 Correlation between perceptions about condoms and intent to use them

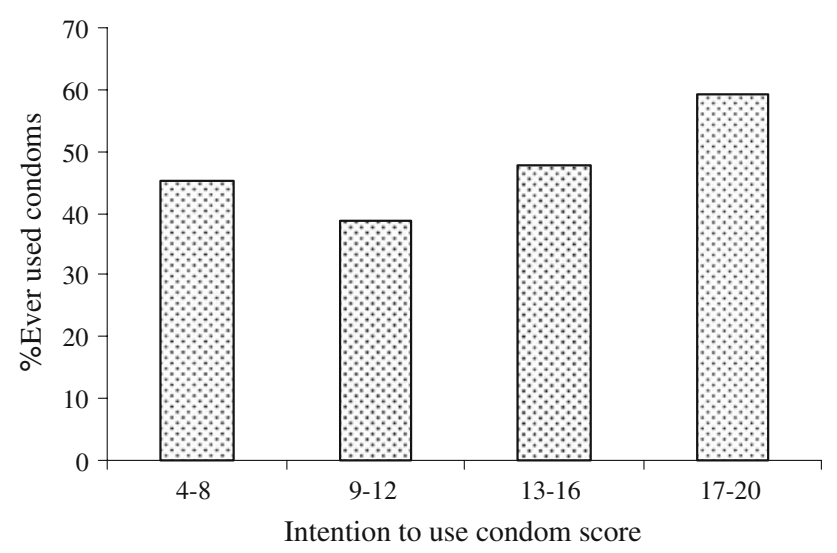

Fig. 2 Relation between intention to use condoms and actual use among all workers who ever had $\operatorname{sex}\left(\chi^{2}(3)=10.35, P<0.05\right)$

been substantial in many areas, due to very low and/or inconsistent use among those at risk. Research in most societies has repeatedly demonstrated negligible condom use even in high-risk settings, creating the opportunity for transmission of HIV and other STIs from high-risk populations to comparatively low-risk populations. This is facilitated by those who act as a bridge for such transmission; i.e., acquiring infection from high-risk groups and spreading them to low-risk groups, such as wives and usual sex partners. Migrant workers are often considered to be one such bridge population (Anderson et al. 2003; Lau and Thomas 2001; Lurie et al. 2003).

In the present study, condom use was consistently low among both local and migrant workers, but particularly among migrants. Overall, only $46.5 \%$ of the participants who had ever had sex had ever used condoms, indicating a large proportion who had never used condoms.
Furthermore, a surprising number of participants, especially local workers, admitted to having sex with males, with whom they never used condoms. As hypothesized, compared to local participants, condom use by the migrant participants was significantly less with wives, FSWs, and other sex partners. A high percentage of married participants in both groups visited sex workers, and only $19.4 \%$ of them always used condoms with FSWs ( $26.5 \%$ of locals vs. $13.8 \%$ of migrants). This was alarming, considering the high likelihood that HIV or other STIs could be transmitted from a core risk group (FSWs) to the wives of these participants, particularly those of migrants. This study also indicated that among these workers, overall, greater intent to use condoms led to greater use of condoms, but not significantly so. Among migrants, although more positive perceptions about condoms increased condom use with FSWs, it was inversely related to condom use with wives. Moreover, neither of the groups showed a very high level of positive perceptions about condoms or intent to use them, and both groups revealed considerable sexual risk behaviors. Although more positive perceptions about condom use were correlated with greater intention to use them, the relationship did not increase intent to a level sufficient to have a significant impact on reducing HIV/STI transmission. Further, intention does not always correlate to action (Ma et al. 2007).

Since this was an initial exploration of migrants in India as a risk group for HIV/STIs, there were several limitations to this study. First, other types of male migrants, most notably inter-district migrants, were excluded due to resource constraints. However, any differences in characteristics between the locals and migrants would likely be most marked, and thereby most easily distinguished between locals and inter-state migrants. Second, the study neither explored the effects of separation from families and cultural factors in predicting risk behaviors of these workers, nor did it try to demonstrate any linkage between sexual risk behaviors of migrants in the settings where they live and work and HIV/STD infection among sex partners in their home communities. Third, we did not assess the extent of sexual activity with different sex partners or the degree to which the desire to have children might have contributed to low rates of condom use by men with their wives, which would provide further information about the risk for HIV and its transmission. Nevertheless, the kind of circumstantial evidence provided by this study is disturbing and a cause for alarm in India, and suggests that more studies focus on examining the linkage between migrants' circumstances in one setting and HIV/STD infection of their sex partners in another setting. Moreover, this study identifies migrant workers as a risk group 
Table 7 Predictors of never using condoms with wife or FSWs: adjusted logistic regression analysis [OR (95\% CI of OR)]

\begin{tabular}{|c|c|c|c|c|c|}
\hline \multirow{2}{*}{$\begin{array}{l}\text { Table } 7 \text { Predictors of never } \\
\text { using condoms with wife or } \\
\text { FSWs: adjusted logistic } \\
\text { regression analysis [OR ( } 95 \% \\
\text { CI of OR)] }\end{array}$} & & \multicolumn{2}{|c|}{$\begin{array}{l}\text { Never used condoms with wife among } \\
\text { ever married }\end{array}$} & \multicolumn{2}{|c|}{$\begin{array}{l}\text { Never used condoms during FSW } \\
\text { visits }\end{array}$} \\
\hline & & $\begin{array}{l}\text { Local workers } \\
(n=155)\end{array}$ & $\begin{array}{l}\text { Migrant workers } \\
(n=262)\end{array}$ & $\begin{array}{l}\text { Local workers } \\
(n=142)\end{array}$ & $\begin{array}{l}\text { Migrant workers } \\
(n=119)\end{array}$ \\
\hline & \multicolumn{5}{|l|}{ Age group (years) } \\
\hline & $18-24$ & $3.7(0.8-16.6)$ & $1.5(0.5-4.2)$ & $0.3(0.1-1.9)$ & $0.2(0.0-1.0)$ \\
\hline & $25-29$ & $2.5(0.7-8.8)$ & $3.0(1.1-7.9)^{*}$ & $0.3(0.1-1.7)$ & $0.3(0.1-1.4)$ \\
\hline & $30-34$ & $1.8(0.5-6.6)$ & $1.3(0.6-3.2)$ & $0.6(0.1-3.4)$ & $0.8(0.2-4.0)$ \\
\hline & $35-39$ & $1.4(0.4-4.9)$ & $2.2(0.8-5.8)$ & $0.3(0.0-2.6)$ & $1.4(0.2-8.2)$ \\
\hline & $40-45$ & Reference & Reference & Reference & Reference \\
\hline & \multicolumn{5}{|l|}{ Education (grades) } \\
\hline & Illiterate $(0)$ & $1.1(0.1-8.2)$ & $3.3(0.4-26.1)$ & $3.2(0.2-40.5)$ & $2.5(0.1-41.3)$ \\
\hline & Primary $(1-4)$ & $0.4(0.1-3.3)$ & $2.7(0.3-21.7)$ & $3.2(0.2-45.9)$ & $1.7(0.1-26.8)$ \\
\hline & Middle (5-8) & $0.4(0.1-2.9)$ & $1.9(0.2-15.6)$ & $2.6(0.2-33.5)$ & $2.1(0.1-34.3)$ \\
\hline & High (9-12) & $0.8(0.1-9.1)$ & $1.2(0.1-11.7)$ & $1.9(0.1-31.2)$ & $0.7(0.0-14.9)$ \\
\hline & College $(>12)$ & Reference & Reference & Reference & Reference \\
\hline & \multicolumn{5}{|c|}{ Average income (rupees/month) } \\
\hline & $<1,000$ & $1.2(0.2-7.3)$ & $0.7(0.1-3.8)$ & $3.4(0.4-27.2)$ & $3.7(0.3-51.7)$ \\
\hline & 1,000 to $<2,000$ & $1.3(0.3-5.4)$ & $0.9(0.2-3.3)$ & $1.5(0.3-6.9)$ & $1.6(0.2-11.4)$ \\
\hline & 2,000 to $<3,000$ & $1.8(0.4-7.8)$ & $0.8(0.2-3.5)$ & $1.5(0.3-7.9)$ & $0.9(0.1-8.0)$ \\
\hline & $\geq 3,000$ & Reference & Reference & Reference & Reference \\
\hline & \multicolumn{5}{|l|}{ Marital status } \\
\hline & Never married & - & - & $0.9(0.3-2.5)$ & $0.8(0.2-3.0)$ \\
\hline & Ever married & & & Reference & Reference \\
\hline & \multicolumn{5}{|c|}{ Ever heard of HIV/AIDS } \\
\hline & Yes & $0.4(0.1-1.9)$ & $0.6(0.2-1.9)$ & $1.1(0.1-10.5)$ & $0.7(0.2-3.2)$ \\
\hline & No & Reference & Reference & Reference & Reference \\
\hline & \multicolumn{5}{|l|}{ Ever visited a FSW } \\
\hline & Yes & $0.5(0.2-1.1)$ & $0.4(0.2-0.7)^{* *}$ & - & - \\
\hline & No & Reference & Reference & & \\
\hline & \multicolumn{5}{|c|}{ Had sex partners other than wife or FSW } \\
\hline & Yes & $1.1(0.4-3.1)$ & $1.4(0.6-3.6)$ & $0.7(0.3-1.3)$ & $0.9(0.3-2.5)$ \\
\hline & No & Reference & Reference & Reference & Reference \\
\hline & \multicolumn{5}{|c|}{ Perceptions about condoms (scores) } \\
\hline & $6-12$ & Reference & Reference & Reference & Reference \\
\hline & $13-18$ & $1.9(0.6-6.1)$ & $4.4(1.7-11.3)^{* *}$ & $2.0(0.6-7.2)$ & $8.6(1.4-52.4)^{*}$ \\
\hline & $19-24$ & $1.2(0.3-4.7)$ & $6.4(1.9-21.2)^{* *}$ & $4.8(0.9-24.2)$ & $4.9(0.5-46.2)$ \\
\hline & $25-30$ & - & $33.2(2.0-543.5)^{*}$ & $3.5(0.2-65.0)$ & $1.9(0.0-104.7)$ \\
\hline & \multicolumn{5}{|c|}{ Intention to use condoms (scores) } \\
\hline & $4-8$ & Reference & Reference & Reference & Reference \\
\hline & $9-12$ & $0.7(0.2-2.6)$ & $0.8(0.3-2.1)$ & $0.4(0.1-1.7)$ & $0.4(0.1-1.6)$ \\
\hline & $13-16$ & $0.8(0.2-3.2)$ & $0.3(0.1-0.9)^{*}$ & $0.1(0.0-0.7)^{*}$ & $0.4(0.1-2.0)$ \\
\hline$* * P<0.01$ & $17-20$ & $0.1(0.0-0.9)^{*}$ & $0.1(0.0-0.4)^{* *}$ & $0.1(0.0-0.5)^{*}$ & $1.4(0.2-11.6)$ \\
\hline
\end{tabular}

$* P<0.05$

** $P<0.01$ for HIV infection in India, with the potential to spread the infection from urban high-risk groups to the general rural population. There is an urgent need for intervention programs to increase the knowledge, perceptions, and intention to use condoms among these workers, designed in the context of low literacy and cultural norms, so that workers develop a clear idea about why they should use condoms, in what circumstances, with whom, and how.

Acknowledgments This work was supported by a grant from NIH/ Fogarty International Center D43 TW000013. We thank Wendy Aft for preparation of the manuscript and editing. 
Open Access This article is distributed under the terms of the Creative Commons Attribution Noncommercial License which permits any noncommercial use, distribution, and reproduction in any medium, provided the original author(s) and source are credited.

\section{References}

Anand, K., Pandav, C. S., \& Nath, L. M. (1999). Impact of HIV/AIDS on the national economy of India. Health Policy (Amsterdam), 47, 195-205. doi:10.1016/S0168-8510(99)00023-8.

Anderson, A., Qingsi, Z., Hua, X., \& Jianfeng, B. (2003). China's floating population and the potential for HIV transmission: A social-behavioural perspective. AIDS Care, 15(2), 177-185. doi: 10.1080/0954012031000068326.

Arole, S., Premkumar, R., Arole, R., Mehendale, S., Risbud, A., \& Paranjape, R. (2005). Prevalence of HIV infection in pregnant women in remote rural areas of Maharashtra State, India. Tropical Doctor, 35(2), 111-112. doi:10.1258/0049475054037110.

Bhatia, V., Swami, H. M., Parashar, A., \& Justin, T. R. (2005). Condom-promotion programme among slum-dwellers in Chandigarh, India. Public Health, 119(5), 382-384. doi:10.1016/j.puhe. 2004.07.004.

CDC. (2002). Male latex condoms and sexually transmitted diseases. Fact Sheet for Public Health Personnel. Centers for Disease Control and Prevention, Atlanta, GA. www.cdc.gov/nchstp/od/ condoms.pdf (last accessed January 02, 2008).

Census of India. (1991). Office of the Registrar General, New Delhi, India.

Census of India. (2001). Office of the Registrar General, New Delhi, India.

Coffee, M., Lurie, M. N., \& Garnett, G. P. (2007). Modelling the impact of migration on the HIV epidemic in South Africa. AIDS (London, England), 21(3), 343-350. doi:10.1097/QAD. 0b013e328011dac9.

Dandona, L., Dandona, R., Gutierrez, J. P., Kumar, G. A., McPherson, S., Bertozzi, S. M., et al. (2005a). Sex behaviour of men who have sex with men and risk of HIV in Andhra Pradesh, India. AIDS (London, England), 19(6), 611-619. doi:10.1097/01.aids. 0000163938.01188.e4.

Dandona, R., Dandona, L., Gutierrez, J. P., Kumar, A. G., McPherson, S., Samuels, F., et al. (2005b). High risk of HIV in non-brothel based female sex workers in India. BMC Public Health, 5, 87. doi:10.1186/1471-2458-5-87.

Dunn, K. M., Das, S., \& Das, R. (2004). Male reproductive health: A village based study of camp attenders in rural India. Reproductive Health, 1, 7-12. doi:10.1186/1742-4755-1-7.

Foss, A. M., Watts, C. H., Vickerman, P., \& Heise, L. (2004). Condoms and prevention of HIV. British Medical Journal, 329, 185-186. doi:10.1136/bmj.329.7459.185.

Go, V. F., Srikrishnan, A. K., Sivaram, S., Murugavel, G. K., Galai, N., Johnson, S. C., et al. (2004). High HIV prevalence and risk behaviors in men who have sex with men in Chennai, India. Journal of Acquired Immune Deficiency Syndrome, 35(3), 314319. doi:10.1097/00126334-200403010-00014.

Gupta, I., \& Mitra, A. (1999). Knowledge of HIV/AIDS among migrants in Delhi slums. Journal of Health \& Population in Developing Countries, 2(1), 26-32.

Haberfeld, Y., Menaria, R. K., Sahoo, B. B., \& Vyas, R. N. (1999). Seasonal migration of rural labour in India. Population Research and Policy Review, 18(6), 471-487. doi:10.1023/A:1006363628308.

Kramer, M. A., van Veen, M. G., Op de Coul, E. L., Geskus, R. B., Coutinho, R. A., van de Laar, M. J., et al. (2008). Migrants travelling to their country of origin: A bridge population for HIV transmission? Sexually Transmitted Infections, 84(7), 554-555. doi:10.1136/sti.2008.032094.

Kumar, A., Mehra, M., Badhan, S. K., \& Gulati, N. (1997). Heterosexual behaviour and condom usage in an urban population of Delhi, India. AIDS Care, 9(3), 311-318.

Lagarde, E., Schim van der Loeff, M., Enel, C., Holmgren, B., DraySpira, R., Pison, G., et al. (2003). Mobility and the spread of human immunodeficiency virus into rural areas of West Africa. International Journal of Epidemiology, 32(5), 744-752. doi: 10.1093/ije/dyg111.

Lamptey, P. R. (2002). Reducing heterosexual transmission of HIV in poor countries. British Medical Journal, 324, 207-211. doi: 10.1136/bmj.324.7331.207. Review.

Lau, J., \& Thomas, J. (2001). Risk behaviors of Hong Kong male residents travelling to mainland China: A potential bridge population for HIV infection. AIDS Care, 13(1), 71-81. doi: 10.1080/09540120020018198.

Li, L., Morrow, M., \& Kermode, M. (2006). HIV and syphilis in migrant workers in eastern China. Sexually Transmitted Infections, 82(1), 11-14. doi:10.1136/sti.2004.014043.

Lurie, M., Williams, B., Suma, K., Mkaya-Mwamburi, D., Garnett, G., Sturm, A., et al. (2003). The impact of migration on HIV-1 transmission in South Africa: A study of migrant and nonmigrant men and their partners. Sexually Transmitted Diseases, 30(2), 149-156. doi:10.1097/00007435-200302000-00011.

Ma, W., Detels, R., Feng, Y., Wu, Z., Shen, L., Li, Y., et al. (2007). Acceptance of and barriers to voluntary HIV counseling and testing among adults in Guizhou Province, China. AIDS (London, England), 21(Suppl 8), S129-S135. doi:10.1097/ 01.aids.0000304708.64294.3f.

National AIDS Control Organization (NACO). (2001). Ministry of Health \& Family Welfare, Government of India. National Baseline General Population Behavior Surveillance Survey, India, 2001.

National AIDS Control Organization (NACO). (2004). Ministry of Health \& Family Welfare, Government of India, Annual Report, 2002-2003, 2003-2004 (up to 31 July 2004), 2004.

National AIDS Control Organization (NACO). (2007a). Ministry of Health \& Family Welfare, Government of India. National AIDS Control Program III (NACP-III) www.nacoonline. org/National_AIDS_Control_Program/Prevention_Strategies (last accessed January 02, 2008).

National AIDS Control Organization (NACO). (2007b). Ministry of Health \& Family Welfare, Government of India. www.nacoonline. org/Quick_Links/HIV_Data (last accessed January 02, 2008).

National Sample Survey (NSS). (1992-1993). National Sample Survey Organisation (NSSO), Ministry of Statistics \& Programme Implementation, Government of India, 1994.

National Sample Survey (NSS). (2001). Report no. 470: Migration in India (1999-2000). National Sample Survey Organisation, Ministry of Statistics \& Programme Implementation, Government of India, New Delhi, September 2001.

Pallikadavath, S., Garda, L., Apte, H., Freedman, J., \& Stones, R. W. (2005). HIV/AIDS in rural India: Context and health care needs. Journal of Biosocial Science, 37(5), 641-655. doi:10.1017/ S0021932004006893.

Panda, S., Chatterjee, A., Bhattacharya, S. K., Manna, B., Singh, P. N., Sarkar, S., et al. (2000). Transmission of HIV from injecting drug users to their wives in India. International Journal of STD and AIDS, 11(7), 468-473. doi:10.1258/ 0956462001916137.

PRAXIS (Institute for Participatory Practices). (2002). MP participatory poverty assessment. Report prepared for Asian Development Bank, New Delhi, India.

Sachdev, P. (1998). Sex on campus: A preliminary study of knowledge, attitudes and behaviour of university students in 
Delhi, India. Journal of Biosocial Science, 30(1), 95-105. doi: 10.1017/S0021932098000959.

Sarkar, S., Das, N., Panda, S., Naik, T. N., Sarkar, K., Singh, B. C., et al. (1993). Rapid spread of HIV among injecting drug users in north-eastern states of India. Bulletin on Narcotics, 45(1), 91-105.

Setia, M. S., Lindan, C., Jerajani, H. R., Kumta, S., Ekstrand, M., Mathur, M., et al. (2006). Men who have sex with men and transgenders in Mumbai, India: An emerging risk group for STIs and HIV. Indian Journal of Dermatology and Venereology, 72(6), 425-431.

Singh, I. N., \& Malaviya, A. N. (1994). Long distance truck drivers in India: HIV infection and their possible role in disseminating HIV into rural areas. International Journal of STD and AIDS, 5(2), 137-138.

Smith-Estelle, A., \& Gruskin, S. (2003). Vulnerability to HIV/STIs among rural women from migrant communities in Nepal: A health and human rights framework. Reproductive Health Matters, 11(22), 142-151. doi:10.1016/S0968-8080(03)02292-4.

Solomon, S., Kumarasamy, N., Ganesh, A. K., \& Amalraj, R. E. (1998). Prevalence and risk factors of HIV-1 and HIV-2 infection in urban and rural areas in Tamil Nadu, India.
International Journal of STD and AIDS, 9, 98-103. doi: 10.1258/0956462981921756.

Sowell, R. L., Holtz, C. S., \& Velasquez, G. (2008). HIV infection returning to Mexico with migrant workers: An exploratory study. The Journal of the Association of Nurses in AIDS Care, 19(4), 267-282. doi:10.1016/j.jana.2008.01.004.

Srivastava, R. S. (1998). Migration and the labour market in India. Indian Journal of Labour Economics, 41(4), 583-616.

Ubaidullah, M. (2004). Social vaccine for HIV prevention: a study on truck drivers in South India. Social Work in Health Care, 39(34), 399-414.

UNAIDS. (2005). The Joint United Nations Programme on HIV/ AIDS. Global Facts and Figures. Factsheet, 22/07/2005.

UNESCO. (2002). Regional Unit for Social and Human Sciences in Asia-Pacific. Regional Workshop on Migration Education, March 18-20, Bangkok, Thailand.

World Health Organization. (2000). Effectiveness of male latex condoms in protecting against pregnancy and sexually transmitted infections. Fact Sheet No. 243, June 2000, WHO, Geneva. http://www.who.int/mediacentre/factsheets/fs243/en/ (last accessed January 02,2008 ). 